\title{
Comparative Analysis of ELV Recycling Policies in the European Union, Japan and China
}

\section{Analiza porównawcza regulacji dotyczących recyklingu ELV w Unii Europejskiej, Japonii i Chinach}

\author{
Jeongsoo $\mathrm{Yu}$ \\ Shuoyao Wang \\ GRADUATE SCHOOL OF INTERNATIONAL CULTURAL STUDIES, TOHOKU UNIVERSITY, \\ 41 KAWAUCHI, AOBA-KU, SENDAI-SHI, MIYAGI PREFECTURE 980-8576, JAPAN \\ wang.shuoyao.q7@dc.tohoku.ac.jp \\ jeongsoo.yu.d7@tohoku.ac.jp \\ Kevin Roy B. Serrona \\ RECYCLING SECTION, RESOURCE RECOVERY DIVISION, DEPARTMENT OF THE \\ ENVIRONMENT, PRINCE GEORGE'S COUNTY 9200 BASIL COURT, SUITE 300, LARGO, \\ MARYLAND 20774, USA \\ krbserrona@co.pg.md.us
}

\begin{abstract}
This research aims at revealing the current status of the End-of-Life Vehicle (ELV) recycling systems in the European Union (EU), Japan and China which are known to have big vehicle manufacturers. The purpose of this research is to clarify their characteristics and issues, such as existing ELV recycling policy, limitations of Extended Producer Responsibility (EPR) and environmental problems caused by secondhand car export. Japanese ELV recycling system will be analyzed as a specific example. Automakers' effort to improve ELV recycling rate and the potential influence on recycling policy from large secondhand car export and NextGeneration Vehicle's (NGV) popularization in Japan will be discussed and generalized. In addition, interview investigation for vehicle makers and government agencies has been conducted to have a comparative analysis of stakeholders' (mainly automakers) attitude towards current ELV recycling law and future plans which can support Next-Generation Vehicle recycling well, as well
\end{abstract}




\title{
Jeongsoo Yu, Shuoyao Wang, Kevin Roy B. Serrona: Comparative Analysis of ELV Recycling Policies in the European Union, Japan and China
}

as cross-border environmental/international resources recycling problems caused by secondhand car export.

\begin{abstract}
Abstrakt
Artykuł ma na celu omówienie obecnego statusu systemów recyklingu pojazdów wycofanych z eksploatacji (ELV) w Unii Europejskiej (UE), Japonii i Chinach, w których działają wielcy producenci pojazdów. Celem tego artykułu jest zatem omówienie zagadnień, takich jak obowiązująca polityka recyklingu pojazdów wycofanych z eksploatacji, ograniczenia rozszerzonej odpowiedzialności producenta (EPR) oraz problemy środowiskowe spowodowane eksportem samochodów używanych. Japoński system recyklingu ELV zostanie przeanalizowany jako przykład. Omówione zostaną także kwestie wysiłków producentów samochodów na rzecz poprawy wskaźnika recyklingu pojazdów wycofanych z eksploatacji oraz potencjalny wpływ na politykę recyklingu pochodzących z eksportu dużych samochodów używanych i popularyzacji pojazdów nowej generacji w Japonii. Ponadto przeprowadzono wywiad dla producentów pojazdów i agencji rządowych w celu dokonania analizy porównawczej podejścia zainteresowanych (głównie producentów samochodów) do obecnych przepisów dotyczących recyklingu pojazdów wycofanych z eksploatacji i planów w zakresie recyklingu pojazdów nowej generacji. Podjęta zostanie także problematyka recyklingu zasobów środowiskowych/międzynarodowych spowodowane
\end{abstract} eksportem samochodów używanych.

\section{Introduction}

The EU (European Union), Japan and Korea have all installed End-of-Life Vehicle (ELV) recycling policy based on Extended-Producer Responsibility principle (EPR). However, the range and subject, the operating condition and the cost allocation of the policy in each country are quite different.

On the other hand, 70\% of ELV in China is recycled by the informal sector which has resulted in serious pollution problems ${ }^{1}$. As a result, the Chinese government introduced EPR in ELV recycling business from 2017, yet specific plan has not been decided. Moreover, Next-Generation Vehicles (NGVs) are increasing globally in recent years, but the recycling aspect has not been fully discussed. Therefore, EPR principle and issues about NGV recycling will be analyzed in this research. Moreover, based

1 Result of interview research on China National Resource Association 
on the field research result, this research will discuss the characteristic and issues of EPR-based ELV recycling policy in EU. Furthermore, after speculating Japanese ELV recycling law and interviewing vehicle makers in Japan, the research intends to introduce the proper state of EPR in the future, including setting a proper ELV recycling fee, decreasing consumers' burden on cost allocation, EPR principle on exported secondhand vehicle and the use of surplus for recycling fee. In addition, ELV recycling policy in China will be comparatively analyzed. Last but not least, NGV recycling problems will be discussed as well. Based on all these results, ELV recycling policy problems in Asia, a proper state of EPR principle and recycling methods for NGV will be shown.

\section{ELV recycling policy and EPR principle \\ 1.1. Transition of EPR principle (background on the enactment of ELV recycling law)}

In advanced countries such as Germany, France and Japan, ELV started to generate massively in the 1980 s and ELV recycling laws were enacted from 2000 to manage and recycle toxic components from ELVs. Generally, $75-80 \%$ of the weight of an ELV will be recycled and the remaining 2025\% will be disposed as Automobile Shredder Residue (ASR) (Ministry of the Environment of Japan 2002).

Figure 1 shows the market of iron scrap (H2) in TOKYO from 1986 to 2008. Although $\mathrm{H} 2$ refers to the iron scrap from demolition of buildings, this can also represent ELV iron scrap price. As Figure 1 shows, the price of iron scrap declined from 1990s to 2005. Moreover, since the price for other non-ferrous metals are also cheap, ELV recycling became chargeable and so, the ASR from ELV may be dumped illegally, toxic and dangerous components such as Chlorofluorocarbon and airbags may be treated inappropriately. To prevent such situation, Japan government established their EPR-based ELV recycling law in 2002 and enacted the law in 2005 . 
Jeongsoo Yu, Shuoyao Wang, Kevin Roy B. Serrona: Comparative Analysis of ELV Recycling Policies in the European Union, Japan and China

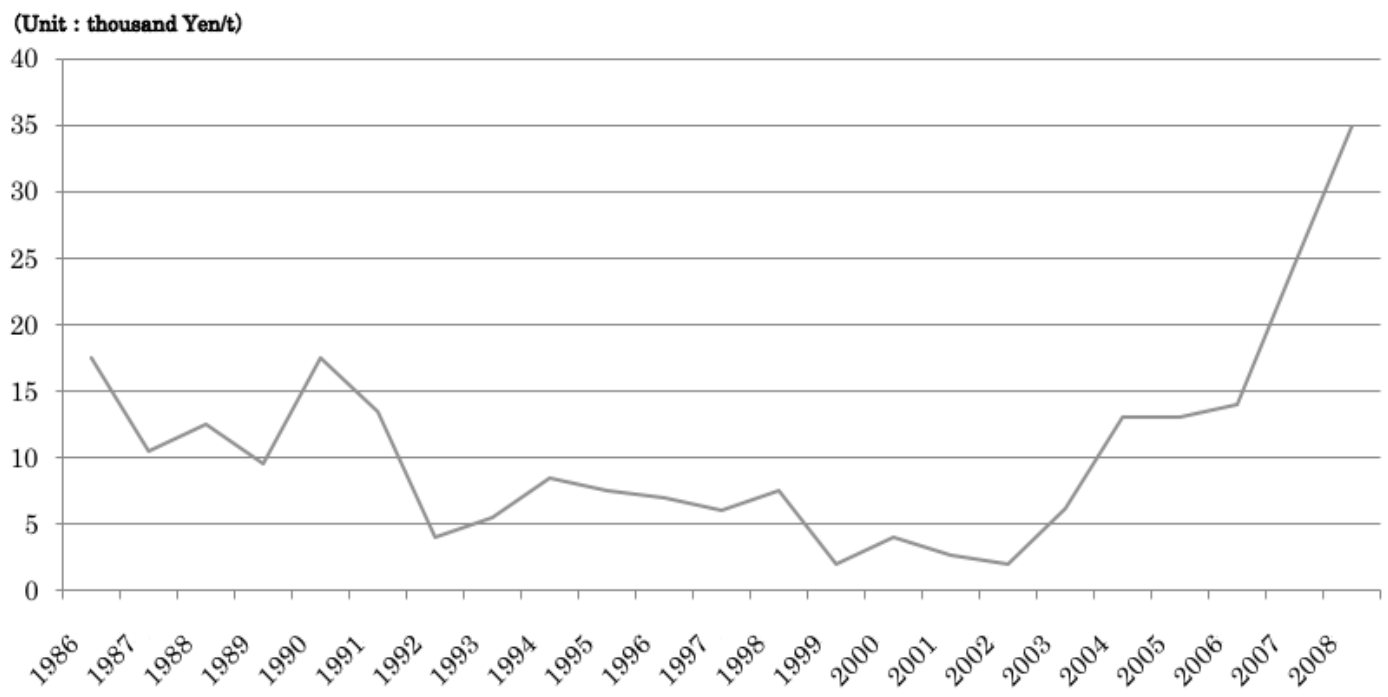

Fig 1: Price for iron scrap (H2) in Tokyo from 1986 to 2008 Figure 1 was created by reference to Japan Metal Bulletin 2016

\subsection{Character and issues of EPR-based ELV recycling law in EU member nations}

In 2000, EPR-based End-of Life Vehicles Directive was proposed and accepted by the European Parliament. EU members nations published their own domestic law referenced to this End-of Life Vehicles Directive ${ }^{2}$. According to the End-of Life Vehicles Directive, vehicle makers and importers share the responsibility to recycle ELV, and pays for the most, or, all of the ELV collection/recycling fee.

In 2000, about nine million vehicles in EU were deregistered, however, 25\% of these ELV were treated inappropriately and were dumped as ASR (Terazono 2002). Considering the situation, End-of Life Vehicles Directive requests that the ELV recycling rate should exceed 85\% (energy recycling rate under $5 \%$ ) from 2006, and 95\% (energy recycling rate under $10 \%)$ from 2015.

However, in 2006, only $50 \%$ of these countries (12 countries) fulfilled the target ( $85 \%$ energy recycling rate is not considered). On the other hand, major automobile makers are mainly located in Germany, France, United Kingdom, Italy and Kingdom of Sweden. However, 3 out of these 5 countries did not reach the expected recycling rate (Italy was 72.7\%, France was 81\%, United Kingdom was 82.3\% based on Eurostat figures).

Therefore, since factors influencing EU's ELV recycling rate is unclear, field study for FCA (Fiat Chrysler Automobiles) and ARN (Auto Recycling

2 Australia and German published domestic ELV recycling law in 2002, and France published domestic ELV recycling law in 2003 etc. 
Netherland) has been operated in March 2017. Based on the result, character of EPR in western European advanced countries has been divided into 3 types.

Table 1: Three types of EPR in EU

Source: Interview research with $A R N$ and $F C A$

\begin{tabular}{|c|c|c|c|c|c|}
\hline & Nation & $\begin{array}{c}\text { Existence of } \\
\text { automobile } \\
\text { manufacturer }\end{array}$ & $\begin{array}{c}\text { Defrayer } \\
\text { for } \\
\text { recycling } \\
\text { fee }\end{array}$ & $\begin{array}{c}\text { Main } \\
\text { Recycling } \\
\text { rate }\end{array}$ & $\begin{array}{c}\text { exportation } \\
\text { for } \\
\text { secondhand } \\
\text { vehicle }\end{array}$ \\
\hline Type A & Netherlands & No & $\begin{array}{c}\text { Vehicle } \\
\text { importer }\end{array}$ & $\begin{array}{c}\text { Around } \\
95 \%\end{array}$ & $\begin{array}{c}\text { Eastern } \\
\text { Europe }\end{array}$ \\
\hline Type B & German & Yes & $\begin{array}{c}\text { Vehicle } \\
\text { maker and } \\
\text { importer }\end{array}$ & $\begin{array}{c}\text { Surpass } \\
100 \%\end{array}$ & $\begin{array}{c}\text { Eastern } \\
\text { Europe }\end{array}$ \\
\hline Type C & Italy & Yes & $\begin{array}{c}\text { Vehicle } \\
\text { maker and } \\
\text { importer }\end{array}$ & $\begin{array}{c}\text { Around } \\
85 \%\end{array}$ & Africa \\
\hline
\end{tabular}

\subsubsection{The Netherlands}

The Netherlands represents countries of Type A, which owns no vehicle maker, and all the vehicles are imported from other countries. Therefore, ELV recycling cost (mainly used for ASR treatment) are all paid by vehicle importers. The RAI (RAI Vereniging: automobile industry association), BOVAG (BOnd Van Automobilelhandelaren en Garagehouders: automobile and bicyle retail association), FOCWA (Federatie van Ondernemers in de Carrosserie- en Wagenbouw en Aanverwante bedrijven: Automobile repair association) and STIBA (Vehicle dismantling dealer association) established ELV recycling association called ARN in 1995.

ARN made contract with about 300 companies including vehicle dismantler and ASR processor and deals with about 85-90\% ELV in the Netherlands. Also, since the land area of the Netherlands is rather small, there is little space for landfill, and so, the ASR has to be reduced during ELV recycling process. Therefore, ASR will be separated in a plant called PST, and then, will be recovered as energy. Thus, ELV recycling rate reached $97 \%$.

However, about 440,00o vehicles are deregistered in the Netherlands and $50 \%$ of these vehicles (mainly high-class vehicle) will be exported to east Europe. The other 50\% will be recycled as ELV in Netherland. As ARN claims, secondhand vehicle exportation follows market principles, and pollution caused by vehicle exportation has not been treated as a problem3.

3 Interview result of ARN 


\subsubsection{Germany}

Germany belongs to type B countries. It owns famous vehicle makers such as Benz and BMW. When ELV recycling became chargeable (such situation is rather rare), vehicle makers will pay for most chargeable fee. Unlike the Netherlands, Germany has plenty of incinerators. Therefore, ASR may not be separated before being combusted in Germany. Since ELV scrap in Germany is less than 20\%, ASR volume for combustion is small.

As ASR incineration produces more ash, it is hard for Germany to accomplish a high recycling rate. Furthermore, according to SCHOLZ (second biggest scrap business company around the world), 80\% of deregistered vehicles in Germany will be exported to eastern EU countries such as Poland (The Japan Society of Industry Machinery Manufactures 2014). Nevertheless, ELV recycling rate in Germany has already surpassed $100 \%$. The reason for this is the Scrap incentive policy which started in 2009. The ELV recycling rate was calculated by Eq. (1).

$$
R=W t / W g(1)
$$

In Eq. (1), $\mathrm{R}$ means ELV recycling rate, Wt shows the weight of recycled ELV in the observation year, and Wg means the weight of ELV generated in the observation year. In Eq. (1), the weight of recycled ELV includes material and thermal recycling at the same time.

After the financial crisis in 2008, the global economy went into recession. To address such situation, Germany introduced scrap incentive policy on January 14, 2009. The policy states that before 31st of December, if a vehicle owner chooses to recycle an old vehicle (used for over 9 years) and buy a new vehicle, he or she will be offered with 2500 Euro. Influenced by this policy, a large part of secondhand vehicles which would be exported to east Europe, was recycled in Germany. Table 2 shows the ELV number of and the recycling rate in Germany.

Table 2: Transition of ELV number and recycling rate in Germany (2006-2014). Source: Eurostat

\begin{tabular}{|c|c|c|c|c|c|c|c|}
\hline & 2008 & 2009 & 2010 & 2011 & 2012 & 2013 & 2014 \\
\hline $\begin{array}{c}\text { Vehicle ownership } \\
\text { (Ten thousand) }\end{array}$ & 4,418 & $4,463.1$ & $4,526.2$ & $4,598.4$ & $4,653.8$ & $4,701.5$ & 4.764 .8 \\
\hline $\begin{array}{c}\text { New vehicle sale } \\
\text { (Ten thousand) }\end{array}$ & 342.5 & 404.9 & 319.8 & 350.8 & 339.4 & 325.8 & 335.7 \\
\hline $\begin{array}{c}\text { Deregistered vehicle } \\
\text { (Ten thousand) }\end{array}$ & 326.6 & 359.8 & 256.7 & 278.6 & 284 & 278.1 & 272.4 \\
\hline ELV emerge Rate & $7.4 \%$ & $8.1 \%$ & $5.7 \%$ & $6.1 \%$ & $6.1 \%$ & $5.9 \%$ & $5.7 \%$ \\
\hline $\begin{array}{c}\text { Domestic recyeled } \\
\text { ELV }\end{array}$ & 41.8 & 117.9 & 50 & 46.6 & 47.7 & 50 & 51.2 \\
\hline ELV Collection rate & $12.8 \%$ & $49.4 \%$ & $19.5 \%$ & $16.7 \%$ & $16.8 \%$ & $18 \%$ & $18.8 \%$ \\
\hline
\end{tabular}

Under the scrap incentive program, Germany recycled 1.78 million ELVs in 2009. This number shrunk to merely 400-500 thousand in other years. On the other hand, ELV recycling rate was increasing from 2006- 
2008, and decreased largely in 2009, and increased/surpassed 100\% from 2010. The reason for this change is ELVs which emerged in 2009 was not completely recycled. Therefore, since 2010, ELV treatment weight is larger than the actual collected ELV weight.

Actually, to show the data in table 2, annual vehicle deregistration number was investigated in this research. However, since the data is not available, it is calculated by Eq. (2).

$$
V d=V o p+V r c-V o c(2)
$$

In Eq. (2), Vd stands for vehicle deregistration number this year, Vop means vehicle ownership in the end of preceding year, Vrc is vehicle registration number this year, and Voc is vehicle ownership this year. Although vehicle deregistration number includes new vehicle sales as well as imported secondhand vehicles. Since imported vehicles are few, it can be treated as none. Therefore, Eq. (2) converts to Eq. (3).

$$
V d=V o p+V s c-V o c(3)
$$

In Eq. (3), Vsc means new vehicle sales for the year. Using Eq. (3), vehicle deregistration number in Germany could be stimulated. Moreover, after knowing the deregistered vehicle number, ELV emerge rate can be calculated by dividing vehicle deregistered number by vehicle ownership in the same year.

As table 2 shows, ELV emerge rate in Germany from 2010 was stable at six percent. Also, these deregistered vehicles were either exported abroad or recycled within Germany by a qualified recycling operator. The recycling rate mentioned earlier was calculated based on ELVs which were actually left in Germany.

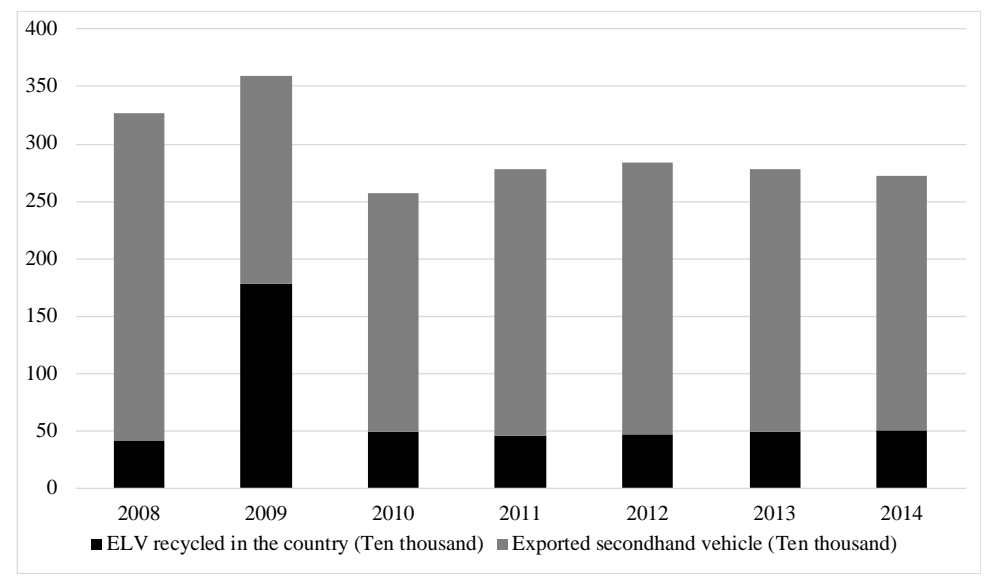

Figure 2: Flow and transition of ELV in Germany Source: OICA data

As Figure 2 shows, besides 2009, when the scrap incentive policy 
was enforced, domestic ELV recycling rate is under 20\%. Although most east Europe countries, which are also the main export destination for Germany secondhand vehicles, also installed domestic ELV recycling law based on ELV directive, the execution is often not appropriate, and a significant number of ELV were given to unauthorized recycling operators. Therefore, monitoring of exported ELV was nearly impossible and caused environmental problems.

In Poland, a major export destination, 90\% of ELVs are recycled by the unauthorized ELV recycling operators who cares little for the environment. Polish government can only monitor and recycle $10 \%$ of all the ELV. For EPR policy in EU, it is important to solve this kind of issue in the future.

\subsubsection{Italy}

Italy represents countries of type C. Similar to Germany, Italy also has car manufacturers and the principle on ELV recycling cost allocation is the same.

As for the differences, Italy does not own incineration facilities, and will landfill ASR directly. The reason is that the price of ASR landfill is cheaper than building an incineration facility. Also, there is a strong public opposition to building incineration facilities. Therefore, ELV recycling rate in 2015 was only around $84.7 \%$, and the thermal recycling rate was only $0.1 \%$. Also, Italian secondhand vehicles are mainly being exported to African countries instead of eastern European countries. The reason is Africa is closer to Italy than eastern Europe, and cheap secondhand vehicles are more popular in African countries compared with eastern European countries. However, since these secondhand vehicles can only be exported by ship, there will be a quantity limitation for the exportation 4 .

\subsection{Character and issues of EPR-based ELV recycling law in Asian countries}

\subsubsection{Japan}

Since 1978, some rogue enterprises started to transport, burn,landfill industrial waste and ELV ASR in Teshima island. Although these enterprises claim they are "Oligochaete farming by harmless industry waste", the treatment brought huge health harm to the island people. Yet, Kagawa prefecture government defended illegal waste dealers by claiming these industrial wastes as ingredients for metal recycling. In 1990, Police in Hyogo prefecture finally accused these illegal waste dealers for treating industrial waste inappropriately. In 1993, Teshima citizens ask these dealers to stop through pollution mediation (Oliver-foundation).

4 Result of interview research on Italian vehicle maker FCA 
As a result of the Teshima affair - the most famous illegal industrial waste dumping case in Japan, part of the Japanese Waste Disposal \& Public Cleaning Law has been amended. Since 1995, ASR is mandated to be dumped in controlled landfill sites and the cost for ASR treatment soared, as final disposal sites' capacity decreases (Ministry of the Environment 2013).

What's more, since 1990 s to 2004, iron scrap prices stagnated, and the ELV recycling became chargeable. This caused ELV and ASR illegal dumping problem and so, it became important for Japan to establish a reasonable and operational EPR-based ELV recycling system. As a result, the treatment of illegally dumped waste in Teshima ended in March 2017 (MIZUNO 2018).

Inspired by the ELV directive of the EU, the Japanese government enacted the End-of-Life Vehicle Recycling Law in July 2002 and put into force in January 2005. As the law describes, vehicle manufacturer and/or vehicle importers are tasked to take responsibility on collecting and recycling the ASR, airbag and fluorocarbons. Also, recycling fee varies for each type of vehicle, besides information management cost (130 Yen) and fund management cost (290 Yen, this could be 410 Yen if not paid in advance), each vehicle will be charged for about 6,000 yen to 18,000 as recycling cost 5 . However, the ELV recycling cost is not decided by the government, but by vehicle manufacturer and importer.

Table 3: Standard for calculating ELV recycling cost Source: Interview research with MITSUBISHI and SUBARU

\begin{tabular}{|c|c|}
\hline Subject & standard for recycling cost calculation \\
\hline ASR & Weight of ASR \\
\hline Airbag & Recent cost for treatment (Varies from the number of airbag) \\
\hline Chlorofluorocarbon & Whether equipped with AC, type of CFC, recent cost for recycling \\
\hline
\end{tabular}

Under the competition principle, vehicle manufacturers in Japan are divided into two groups, "TH team (Toyota, Honda)" and "ART team (Nissan, Mitsubishi, Subaru, etc.)" to recycle ASR, airbag and fluorocarbons. However, since ELV recycling cost was too high, vehicle makers started to benefit for billions of Yen every year after a short period of deficit at first.

Also, a large amount of surplus occurred from the recycling fee kept in Japan Automobile Recycling Promotion Center (JARC). This kind

5 Information management cost and fund management cost have changed after the enforcement of ELV recycling law, in this research, this cost prementioned is for November 2017 
of surplus is called "Specified Recycling Deposit." Reasons for this surplus to occur and the specific number (interest is not included) are shown below (Ministry of Economy, Trade and Industry 2016 a):

1. No request for refund of recycling fee after secondhand vehicles' exportation

2. No need for treatment of ASR such as being exported by an unauthorized dealer as ELV shell (Whole dismantled)

3. No need for treatment of CFC by reusing CFC

4. No need for treatment of CFC and airbag under situations such as an accident etc.

At the end of 2015, the Specified Recycling Deposit (interest included) reached 19.1 billion yen, of which 5.6 billion have been used efficiently with a balance of 13.6 billion yen (Japan Automobile Recycling Promotion Center 2016). Until this point, the appropriation of Specified Recycling Deposit is about 5.6 billion, and stationary appropriation is only 150 million yen per year (to solve problems such as illegal dumping etc.). On the other hand, the number of Specified Recycling Deposit is around 1.5 billion yen per year which shows surplus more than the appropriation (Ministry of Economy, trade and Industry 2016 a).

Table 4: Transition for the occurrence of Specified Recycling Deposit Source: Japan Automobile Recycling Promotion Center, 2016

\begin{tabular}{|c|c|c|c|c|c|c|c|c|c|c|c|c|c|}
\hline \multicolumn{2}{|c|}{ Reason } & 2006 & 2007 & 2008 & 2009 & 2010 & 2011 & 2012 & 2013 & 2014 & 2015 & $\begin{array}{l}\text { Sum } \\
(2004- \\
2015)\end{array}$ & Ratio \\
\hline \multicolumn{2}{|c|}{ Vehicle exportation } & 0 & 90 & 757 & 789 & 577 & 331 & 328 & 325 & 465 & 336 & 3,997 & $22.86 \%$ \\
\hline \multicolumn{2}{|c|}{ Whole dismantled } & 864 & 511 & 514 & 270 & 486 & 377 & 387 & 397 & 452 & 346 & 6,066 & $34.7 \%$ \\
\hline \multicolumn{2}{|c|}{ Reuse of CFC } & 120 & 116 & 117 & 107 & 107 & 104 & 74 & 64 & 62 & 52 & 938 & $5.37 \%$ \\
\hline \multirow{2}{*}{$\begin{array}{l}\text { Fund surplus } \\
\text { from } \\
\text { accidents }\end{array}$} & Airbag & 139 & 217 & 268 & 283 & 304 & 318 & 371 & 357 & 336 & 311 & 2,965 & $16.96 \%$ \\
\hline & CFC & 180 & 334 & 358 & 341 & 352 & 387 & 436 & 393 & 339 & 334 & 3,516 & $20.11 \%$ \\
\hline \multicolumn{2}{|c|}{ Sum (million yen) } & 1,303 & 1,268 & 2,014 & 1,790 & 1,826 & 1,517 & 1,597 & 1,536 & 1,654 & 1,578 & 17,483 & $100 \%$ \\
\hline
\end{tabular}

Under this situation, the Ministry of Economy, Trade and Industry of Japan is planning to use Specified Recycling Deposit to make a discount on ELV recycling fee for vehicles which uses recovered plastic from ELV. This policy will be enforced for 10 years and is predicted to start after 2022. According to the assumption, the target number of vehicles will be 100 thousand per year, and the discount is 10,000 Yen per vehicle, and so, the appropriation is around 1 billion per year. However, the collection and recycling of plastic from ELV is quite expensive, and since the plastic price fluctuates greatly according to oil market, 
it is hard to predict if the policy will be as efficient as expected. Moreover, even if this policy is enacted, Specified Recycling Deposit is still larger than appropriation. That means the use of Specified Recycling Deposit is still inefficient and the balance will still increase.

According to EPR-based ELV recycling law in Japan, the recycling cost is paid for by vehicle owners, and the object of the law is limited to three items only. Furthermore, the recycling (physical responsibility) of these three items is actually operated by recycling dealers instead of vehicle manufacturers. Financial responsibility of vehicle makers is merely on the initial cost for building the system and its running cost. The initial cost is about 10 billion and the running cost is around 1.3 billion per year. These costs are paid for by vehicle makers and allocated based on each maker's market share.

However, the benefit from recycling business has surpassed the cost largely, and revenue is much more than expenditure for each vehicle maker. Therefore, further discussion about the utilization for vehicle maker's benefits from recycling the ELV and the Specified Recycling Deposit generated from ELV recycling system is necessary.

\subsubsection{China}

The first policy based on EPR principle in China is "Reuse/recycling technology and policy for automobile components" which was published in 2006. Except for policy on remanufacturing of vehicle components, China lacks EPR-related policies.

Vehicle manufacturers in China, including Japanese automakers such as Toyota and Honda, made little effort in exercising EPR principle. For instance, in Japan, automobile manufacturers started to publish "Environmental report" and "CSR (Corporate Social Responsibility) report" since the late 1990s, however, in China, these manufactures have just started to do the same thing in recent years, and the content related to EPR in "CSR report" EPR is also limited.

Table 5 shows the effort made on EPR by Japanese and Chinese vehicle makers in China. Among the seven (7) Japanese automobile makers in China, only two companies published CSR report, and GAC TOYOTA is the most positive one. Even so, it still cannot match the effort they made back in Japan. Among eight (8) Chinese vehicle makers of which six (6) companies published CSR report, only three (3) companies (CHANGAN, GEELY and DONGFENG) took actual action on EPR. The most positive one is GEELY. Two reasons have been proposed. One is GEELY's attempt to export vehicles to EU, and therefore they have to fulfill the request of EU's ELV directive, which requires recyclability for ELV should reach 95\% (thermal recycling rate less than 10\%), and restriction for usage of toxic subjects. Another reason could be that GEELY bought all the shares of VOLVO, a Sweden vehicle maker, and so, affected by VOLVO, environment consciousness has been developed. 
Jeongsoo Yu, Shuoyao Wang, Kevin Roy B. Serrona: Comparative Analysis of ELV Recycling Policies in the European Union, Japan and China

Table 5: Efforts towards EPR of vehicle makers in China Source: Chinese vehicle makers

\begin{tabular}{|c|c|c|c|c|}
\hline Subject & Vehicle maker & CSR report & Effort for EPR & Achievement \\
\hline \multirow{7}{*}{$\begin{array}{l}\text { Japarese vehicle } \\
\text { makers }\end{array}$} & FAW TOYOTA & No & No & No \\
\hline & GAC TOYOTA & Yes (since 2013) & $\begin{array}{c}\text { Design and development } \\
\text { of eco-produst }\end{array}$ & $\begin{array}{l}\text { Recycling rate surpassed } 95 \% \\
\text { for all types of vehicle }\end{array}$ \\
\hline & GAC HONDA & No & No & $\begin{array}{l}\text { Recycling rate surpassed } 90 \% \\
\text { for all types of vebicie }\end{array}$ \\
\hline & $\begin{array}{c}\text { DONGFENG } \\
\text { HONDA }\end{array}$ & Yes (since 2012) & No & No \\
\hline & $\begin{array}{l}\text { DONGFENG } \\
\text { NISSAN }\end{array}$ & No & Remanufacture service & $\begin{array}{l}\text { Published "Guidebook for } \\
\text { circulation design" to improve } \\
\text { resource saving and recyeling }\end{array}$ \\
\hline & $\begin{array}{l}\text { ZHENGZHOU } \\
\text { NISSAN }\end{array}$ & No & No & No \\
\hline & $\begin{array}{c}\text { GAC } \\
\text { MITSUBISHI }\end{array}$ & No & No & No \\
\hline \multirow{8}{*}{$\begin{array}{c}\text { Chinese vehicle } \\
\text { makers }\end{array}$} & CHANGAN & Yes (since 2016) & No & $\begin{array}{l}\text { Published manual book for } \\
\text { vehicles sold after } 2016\end{array}$ \\
\hline & GREATWALL & No & No & No \\
\hline & CHERY & No & No & No \\
\hline & CHINA FAW & Yes (since 2008) & No & No \\
\hline & GEFIY & Yes (since 2012) & $\begin{array}{l}\text { 1.Cansideration for } \\
\text { recyclability during } \\
\text { design process } \\
\text { 2. Monitoring on use of } \\
\text { toxic subject }\end{array}$ & $\begin{array}{l}5 \text { types of vehicle reached } \\
\text { recyclability and material } \\
\text { recyclability target }\end{array}$ \\
\hline & QAC GROUP & Yes (since 2013) & No & No \\
\hline & DONGFENG & Yes (since 2008) & No & OWns vehicle recycline plant \\
\hline & BYD & Yes (since 2010) & No & No \\
\hline
\end{tabular}

\section{Interview research on vehicle makers' consciousness about issues on ELV recycling}

\subsection{Japan}

\subsubsection{Efforts of TOYOTA on EPR}

TOYOTA took positive and voluntary efforts towards EPR as a world-class vehicle maker. According to their report in 2017, three actions have been taken in realizing a circulation type of environmental society:

1. Reduced the usage of exhaustible natural resources by using recoverable and recycled material. 
A. To reduce the use of resin from oil, TOYOTA collects and recycles components such as bumpers of ELV from dealers.

B. Under the concept of "car to car" reuse of rare resources and recycled materials, the collection, reuse and recycling of components (batteries, motor magnetite and harness) from NGV (mostly HV at present).

2. Used easily separable technology and components

A. TOYOTA established "ELV recycling research institute" in 2001 and have worked for over 10 years on developing easy and efficient dismantling technology for ELV.

3. Promoted international cooperation on ELV recycling

In 2016, TOYOTA planned to make an "ELV recycling manual" for countries and regions lacking proper recycling facilities or tools, and plans to build 100 recycling plant abroad until 2050 (TOYOTA 2017).

On the other hand, the author has sent a questionnaire about EPR of ELV recycling to the environment department of TOYOTA thrice, but quoting their reply, "except for the content from published reports, the questionnaire is hard to answer due to information security concerns". Although TOYOTA did have a scheme to recycle driving batteries from their NGVs, questions about recycling technology and situation for NGV ( $\mathrm{HV}$ in this case) and the batteries inside Japan, and the strategies for recycling HVs abroad was also not well answered compared to other companies like MITSUBISHI and SUBARU. To conclude, Toyota is at the top on EPR in Japan, but they did not reply well to the survey compared to MITSUBISHI and SUBARU, where similar questions were well answered.

\subsubsection{Efforts of MITSUBISHI on EPR}

In 1998, MITSUBISHI made "Initiative for ELV recycling of MITSUBISHI". Moreover, since 1999, they published "Guidelines for recycling design" which was aimed at improving design for the environment. According to their report in 2017 and vehicles' environmental specification document, their strategies are listed below (MITSUBISHI 2017).

1. Indication for resin and rubber parts

2. Decrease the degree of difficulty for dismantling wires, harness and motors based on "Guideline for the design of harness"

3. Recycle bumpers from dealer and use recycled materials in manufacturing components such as battery tray and covers.

4. Recycling technology and policy development for Electric Vehicles and Plug-in Hybrid Vehicles.

What's more, according to MITSUBISHI, they also published manual to recycle driving battery form their EV and PHEV.

\subsubsection{Efforts of SUBARU on EPR}

Based on "CSR report 2017" (SUBARU 2017), and vehicles' environmental specification document from SUBARU, the activities include: 
1. Improve design for environment

2. Recycle waste parts from dealers. Waste parts include lead battery, oil, tire and bumper.

Besides all these actions, common activities, such as decrease in the use of toxic materials (lead, mercury, Hexavalent chromium and cadmium) and disclose information for dismantling and collecting CFCs, airbags, batteries, parts containing cooper and rare metal have been taken.

Furthermore, SUBARU is also planning on building their own driving battery recycling system.

\subsubsection{Comparison of MITSUBISHI and SUBARU based on interview research}

Interview with MITSUBISHI and SUBARU was conducted in August 2017. The content was about EPR and consisted of five (5) parts.

1. Cost spent for recycling during vehicle design process

2. Design parts which can be easily dismantled and recycled

3. Voluntary activity for EPR

4. Recycling of 3 items (CFC, airbag and ASR) based on ELV recycling law

5. Advices for improving Japanese ELV recycling system

Since part of question 2 and 3, and question 4 have been discussed before, results of other questions are listed as below.

Table 6: Comparison of interview research results from MITSUBISHI and SUBARU

Source: Interview research with MITSUBISHI and SUBARU

\begin{tabular}{|c|c|c|}
\hline & MITSUBISHI & SUBARU \\
\hline $\begin{array}{l}\text { Cost spent for recycling during } \\
\text { design process }\end{array}$ & incalculable & $\begin{array}{l}\text { incalculable, but investment for } \\
\text { environment protection project is } 14 \\
\text { billion, and the cost is } 347 \text { billion. }\end{array}$ \\
\hline $\begin{array}{l}\text { Time for easy dismantling and } \\
\text { recycling technology } \\
\text { development }\end{array}$ & $\begin{array}{l}\text { Start to develop vehicles with easy } \\
\text { dismantling technology since late } \\
1990 \mathrm{~s}\end{array}$ & $\begin{array}{l}\text { Published "Voluntary plan for } \\
\text { recycling ELV" in } 1998\end{array}$ \\
\hline $\begin{array}{l}\text { Achievement in increase ELV } \\
\text { dismantling efficiency }\end{array}$ & $\begin{array}{l}\text { Find the components with high } \\
\text { reuse rate, set targets for ELV } \\
\text { dismantling time }\end{array}$ & No answer \\
\hline $\begin{array}{l}\text { Vehicle which is equipped with } \\
\text { easy dismantling technology }\end{array}$ & All types of vehicle & All types of vehicle since 1998 \\
\hline $\begin{array}{l}\text { Reason for improving ASR } \\
\text { recycling rate from } 60 \% \text { to } 95 \%\end{array}$ & $\begin{array}{l}\text { The plan is practiced by related } \\
\text { institution and dealer under clear } \\
\text { responsibility allocation }\end{array}$ & $\begin{array}{l}\text { Competition between TH team and } \\
\text { ART team on ELV recycling business }\end{array}$ \\
\hline $\begin{array}{l}\text { Reason for installing stricter } \\
\text { EPR-related policy }\end{array}$ & $\begin{array}{l}\text { 1. To make recycling society and } \\
\text { reduce recycling cost } \\
\text { 2.Responsibility as a vehicle maker }\end{array}$ & $\begin{array}{l}\text { Evaluate environment impact } \\
\text { throughout all life cycle process of a } \\
\text { product to protect the environment }\end{array}$ \\
\hline $\begin{array}{l}\text { Merit and demerit for } \\
\text { supporting EPR }\end{array}$ & No answer & $\begin{array}{l}\text { Merit: Value improvement for the } \\
\text { company and may decrease the cost } \\
\text { Demerit: Possibility of no } \\
\text { achievement despite the effort }\end{array}$ \\
\hline $\begin{array}{l}\text { Advice for the correction of } \\
\text { ELV recycling system }\end{array}$ & Keep revenue and expenditure even & Appropriately \\
\hline
\end{tabular}


As shown in table 6, during vehicle designing process, it is unable to predict ELV recycling fee, as MITSUBISHI claims, the cost spent for improving environmental conservation activities is 34.7 billion, occupying $38.99 \%$ of all cost for research and development (R\&D). Compared to total investment cost, this occupied $2.41 \%$. The reason for this unusual proportion may be the indemnity for mileage injustice issue in 2016.

Also, these 2 companies started to develop dismantling technologies since 1990s. There are two (2) reasons for this action:

First, in 1997, the initial version of ELV directive was published and Japanese vehicle makers in EU have to follow the policy.

Secondly, Japanese Ministry of International Trade and Industry published "ELV recycling incentive" in May 1997 which requires vehicle makers to pay attention to vehicles' recyclability.

However, the actual improvement in vehicles' recyclability is not clear. Although SUBARU is making effort to decrease ELV dismantling time, and yet, specific data is still not clear. Also, as mentioned in previous paragraph, vehicle makers start to get a benefit from recycling ELV, and this situation may not be changed simply by decreasing the recycling fees.

\subsection{China}

Interview survey with Japanese vehicle maker (FAW TOYOTA) in China was done in May 2017. According to the result, 1.7 billion Yen have been invested on environmental protection project every year. The most typical one could be tree planting activity around Beijing. Merits and aim of this project are to raise company's brand equity and improve consumers' environmental awareness. However, FAW TOYOTA did not take any effort towards EPR, and there is no voluntary plan for doing it, unless being required by related laws. The reason is that FAW TOYOTA started to sell vehicles in China from 2003 and there are little ELV vehicles right now. As for ELV dismantling manual, although it is not hard to translate Japanese manual into Chinese, it is still not published in China yet. As for component remanufacturing business, since TOYOTA did not start the business in Japan either, it is difficult to say that they are negative only in China. On the other hand, due to Chinese government's policy, FAW cares about vehicle component remanufacturing business a lot, and so, FAW TOYOTA may be affected as well, and may take different action from TOYOTA in Japan.

On the other hand, based on the interview research practiced on May 2017, FAW TOYOTA is trying to persuade people that buying HV is good for the environment, and starts to consider recycling HVs' batteries. However, HVs' technology development has not been treated seriously and they tend to solve the problem after waste batteries came out massively. Under this situation, FAW TOYOTA did not have an operable battery recycling system yet. In order to increase ELV recycling rate in the future, related policy and technology is needed. 


\section{Popularization of Next Generation Vehicle and associated recycling issues}

\subsection{Resource allocation}

In an effort to improve vehicles environmental performance as well as some new functions such as auto drive, Next-Generation Vehicle has become lighter while having more electronic devices than ordinary vehicles.

Considering that vehicle makers are using more plastic, rare metal and high-value metals during the vehicles' manufacture process, the resource potential of one vehicle could have changed significantly. Especially the proportion of iron for an EV may be less than $50 \%$ right now due to the large capacity driving batteries. Therefore, new technology should be installed to recycle End-of-Life NGVs due to their difference in resource content from ordinary vehicles.

Rare metal (nickel, cobalt and lithium) used in an NGV is much more than an ordinary vehicle. As Figure 3 shows, comparing with ordinary vehicles, nickel used in an NGV is 187 times, and cobalt is about 275 times larger. In fact, rare metal used for NGVs' manufacturing business reached 9,000 ton in 2009 (YANO Research Institute 2016) and this consumption may get higher as NGV develops. Thereupon, to reach each country' goal on NGV sales, the stable supply of these specific resources is essential. Recycling resource from End-of-Life NGVs efficiently can satisfy part of the resource demand.

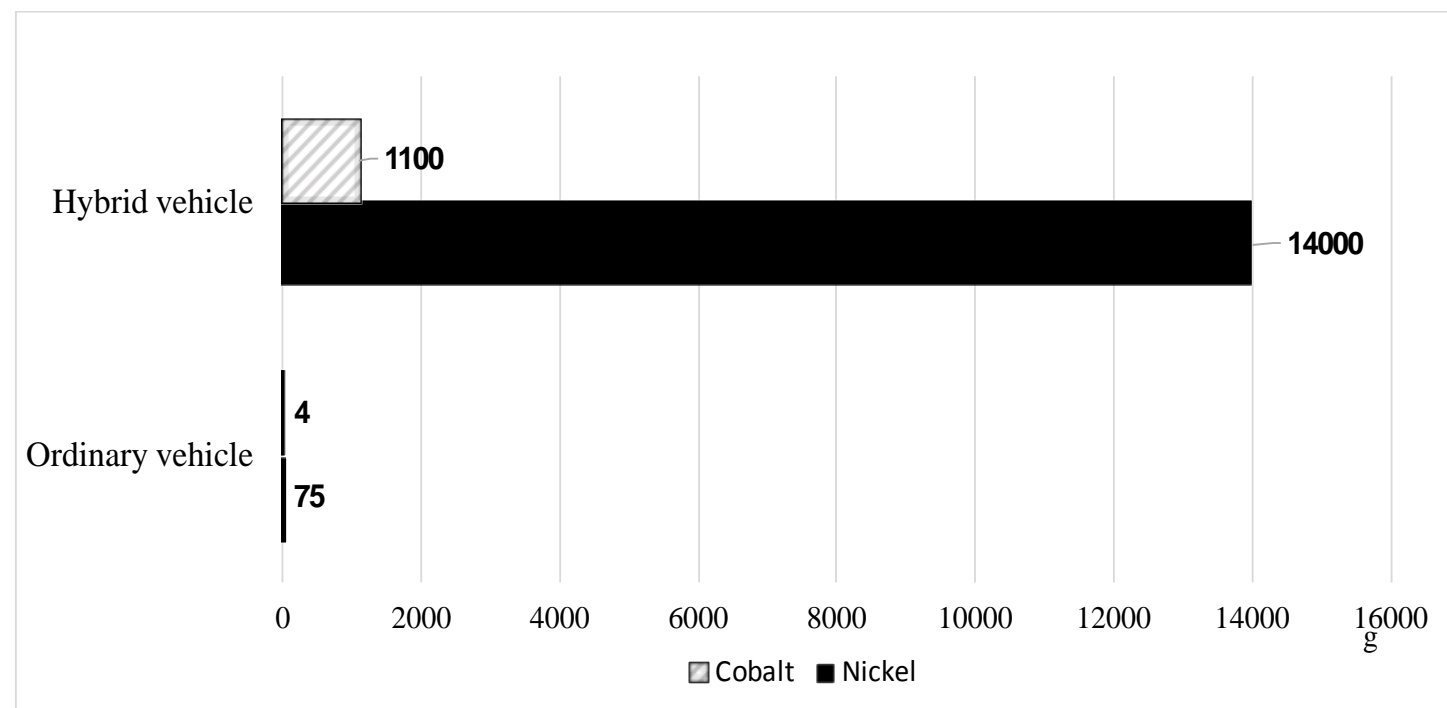

Figure 3: Difference for resource content of NGV and ordinary vehicle Source: Yano J et al., 2016 


\subsection{Secondhand vehicle exportation}

As the sales of NGV increase in Japan, a huge amount of aged NGV are being exported to developing countries, therefore, End-of-Life NGVs recycled in advanced countries are much less than expected. In this section, End-of-Life HV generation status, old HV exportation status and the issues from it in Japan will be introduced.

Hybrid vehicle is the most common NGV. Japan is the first country to sell $\mathrm{HV}$ and owns the biggest $\mathrm{HV}$ market right now. In 2016, about 70\% of $\mathrm{HV}$ in the world were sold in Japan (Fuji Keizai Marketing Research \& Consulting Group 2016; Japan Automobile Manufacturers Association 2018). Meanwhile, within Japan, HV occupied 40\% of total vehicle market (Automotive Industry Portal 2017). The sales of HV are expected to keep increasing fast (Figure 4).

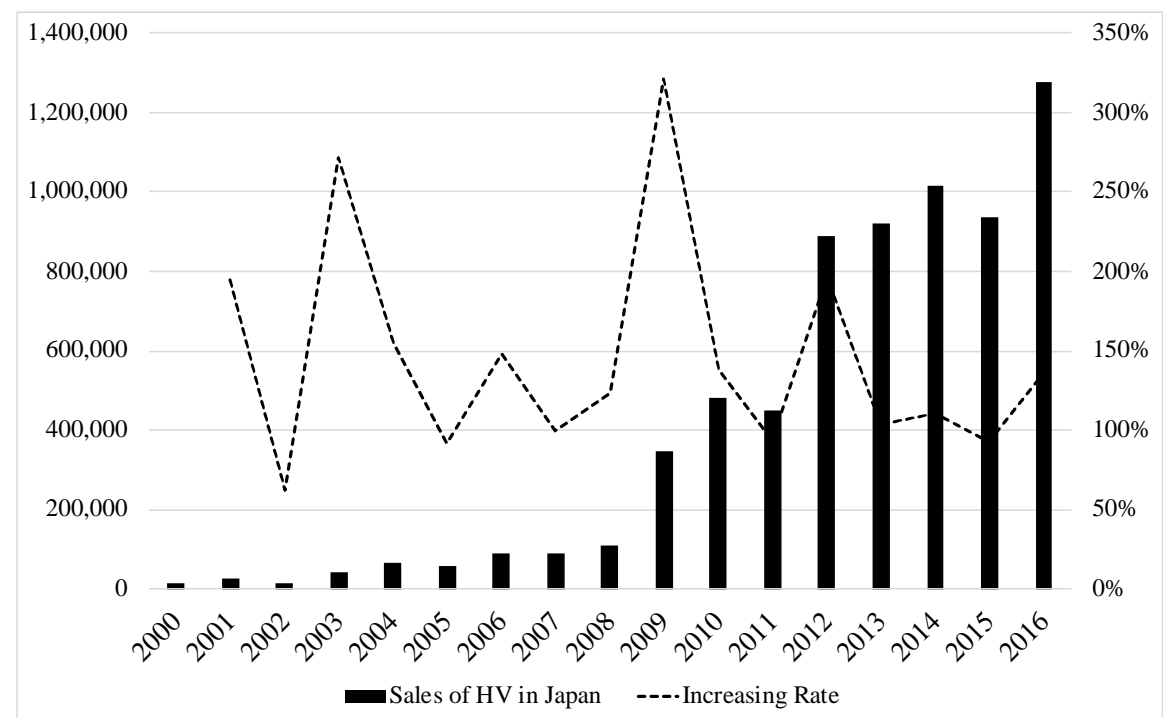

Figure 4: Transition and situation of sale for HV in Japan

Source: Fuji Keizai Marketing Research \& Consulting Group 2016;

Japan Automobile Manufacturers Association 208;

Automotive Industry Portal 2017

HV technology in Japan is quite mature and so Japanese secondhand $\mathrm{HV}$ are considered to have high quality. Therefore, these old HVs are popular and are often transported overseas. According to the Ministry of Economy, Trade and Industry of Japan, in 2013, 13,000 old HV were exported abroad from Japan (Ministry of Economy, Trade and Industry 2016 b), and only 6,000 End-of-Life HV were recycled inside Japan. In 2017, 120,000 secondhand HV were exported from Japan (Hamagin 
Jeongsoo Yu, Shuoyao Wang, Kevin Roy B. Serrona: Comparative Analysis of ELV Recycling Policies in the European Union, Japan and China

Research Institute 2018) and occupied 9\% of the overall secondhand vehicle exportation number in 20176 .

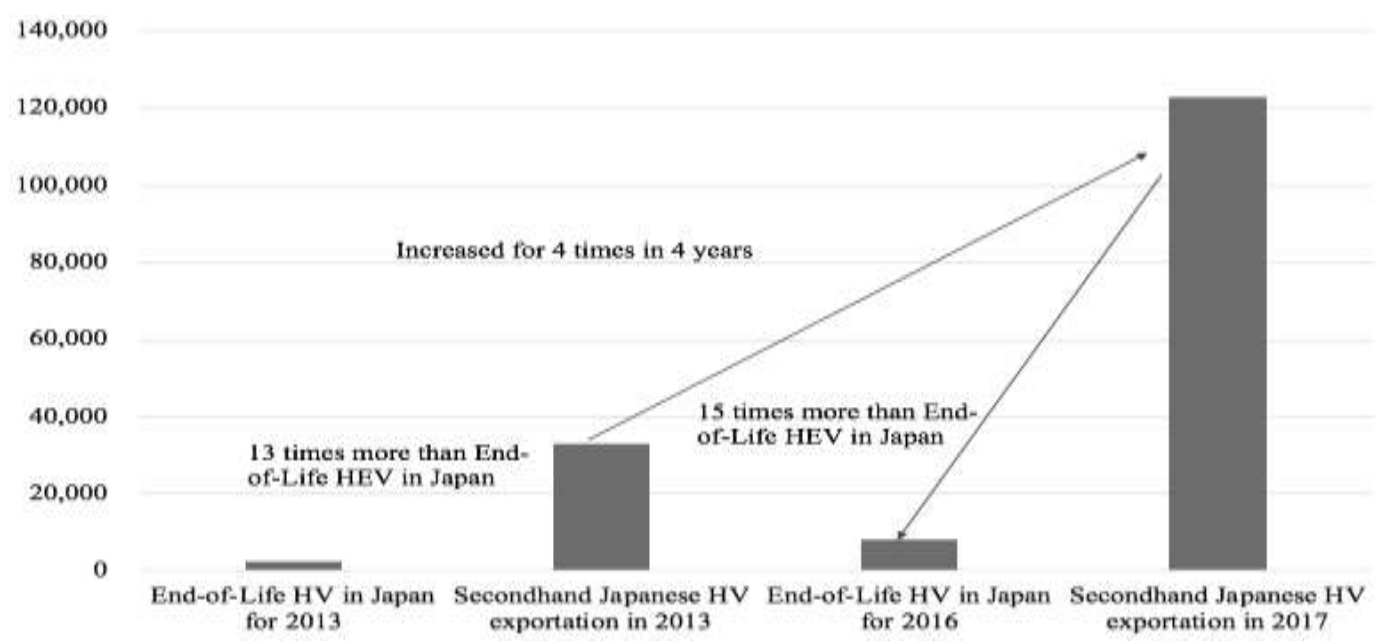

Figure 5: Comparison between secondhand HV exportation and waste HV in Japan

Source: Ministry of Economy, Trade and Industry, 2016 b;

Japan Automobile Recycling Promotion Center, 2016;

Hamagin Research Institute, 2018
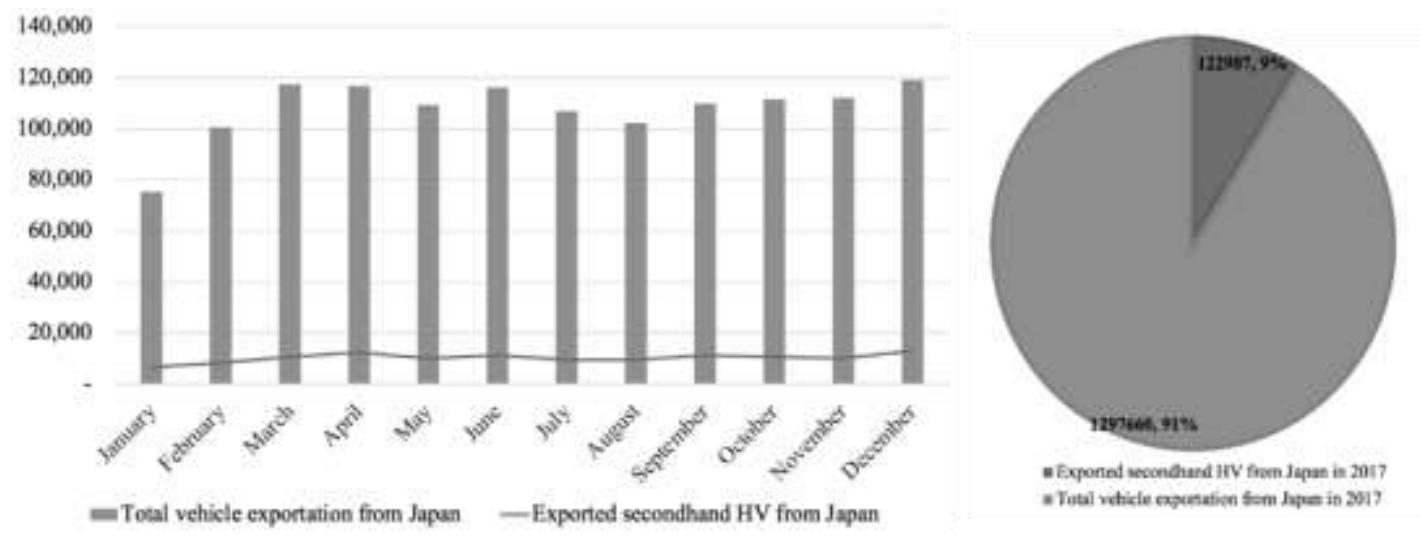

Figure 6: Comparison of exported ordinary vehicle and HV from Japan Source: Hamagin Research Institute, 2018

6 Result of interview research on vehicle used parts dealer in 2017 
Therefore, End-of-Life HV and NiMH batteries will not remain in Japan, instead, these ELV and parts will emerge in developing countries such as Mongolia, Sri Lanka and Pakistan. To prevent resource waste and environmental pollution from End-of-Life HV in Japan and those exported abroad, international resource circulation should be discussed.

As mentioned previously, there are three countries which occupied 56\% (about 69,00o) of all exported secondhand HV from Japan in 2017. Mongolia is the biggest export destination (around 29,000). In fact, since Mongolian HV importation restriction is rather slack, the ratio for HV in all imported vehicles increased from 5\% in 2011 to 36\% in 2014 (Nippon Steel \& Sumikin Research Institute Corporation 2016). These secondhand HV are considered to be imported from Japan mostly. On the other hand, the price of $\mathrm{HV}$ exported to Mongolia from Japan is the cheapest compared to other three countries (10.89 billion Yen), and compared with secondhand HV exported to Sri Lanka and Pakistan, the average price of secondhand HV exported to Mongolia is only 25\%-37\% (Hamagin Research Institute 2018). This means that these HVs' quality may be quite worse and may emerge as ELV fast. Since Mongolia has no proper recycling technology and policy for these vehicles, international assistance from Japan under EPR principle for recycling these HVs is necessary.

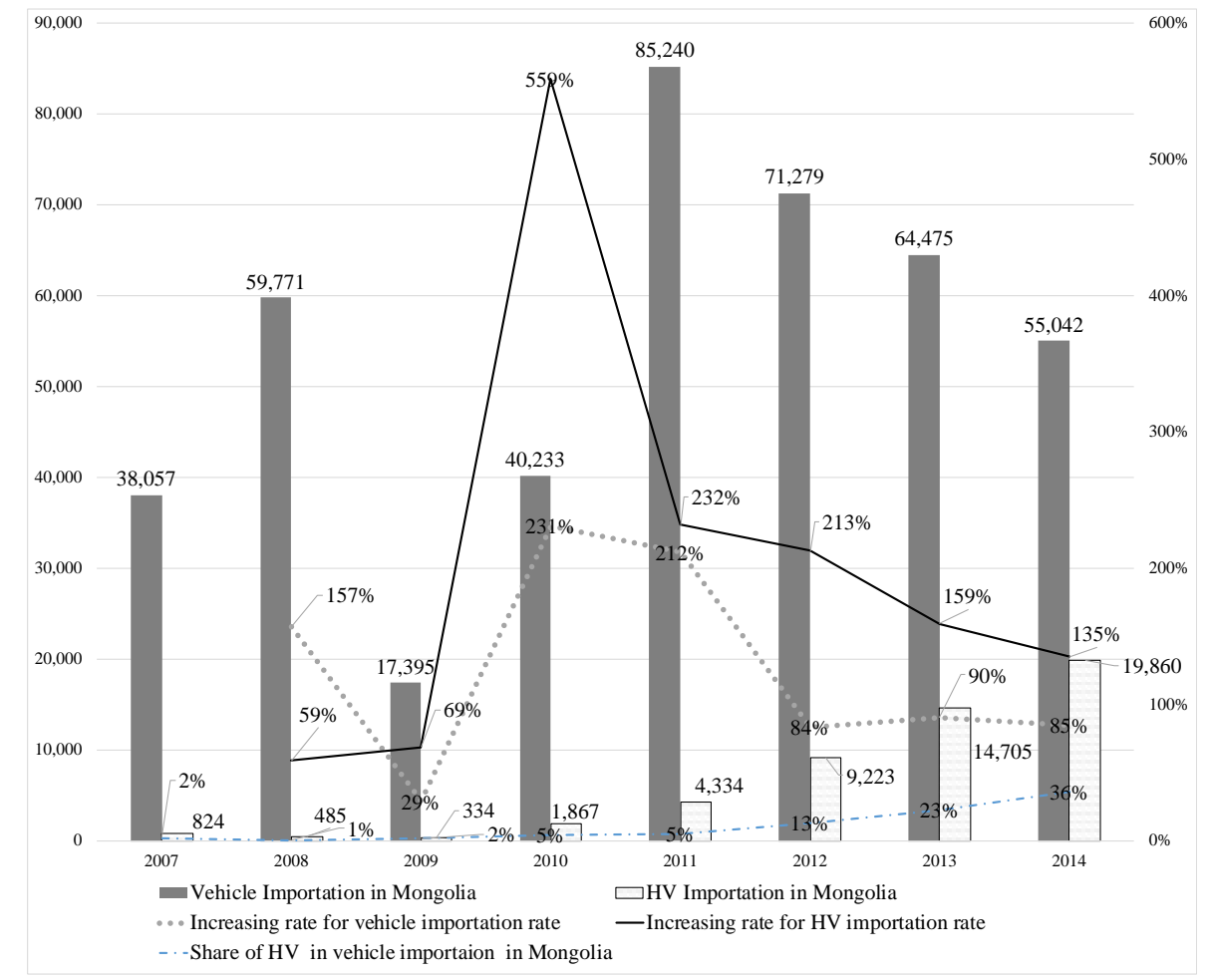

Figure 7: Comparison of HV and ordinary vehicle importation in Mongolia

Source: Nippon Steel \& Sumikin Research Institute Corporation, 2016 


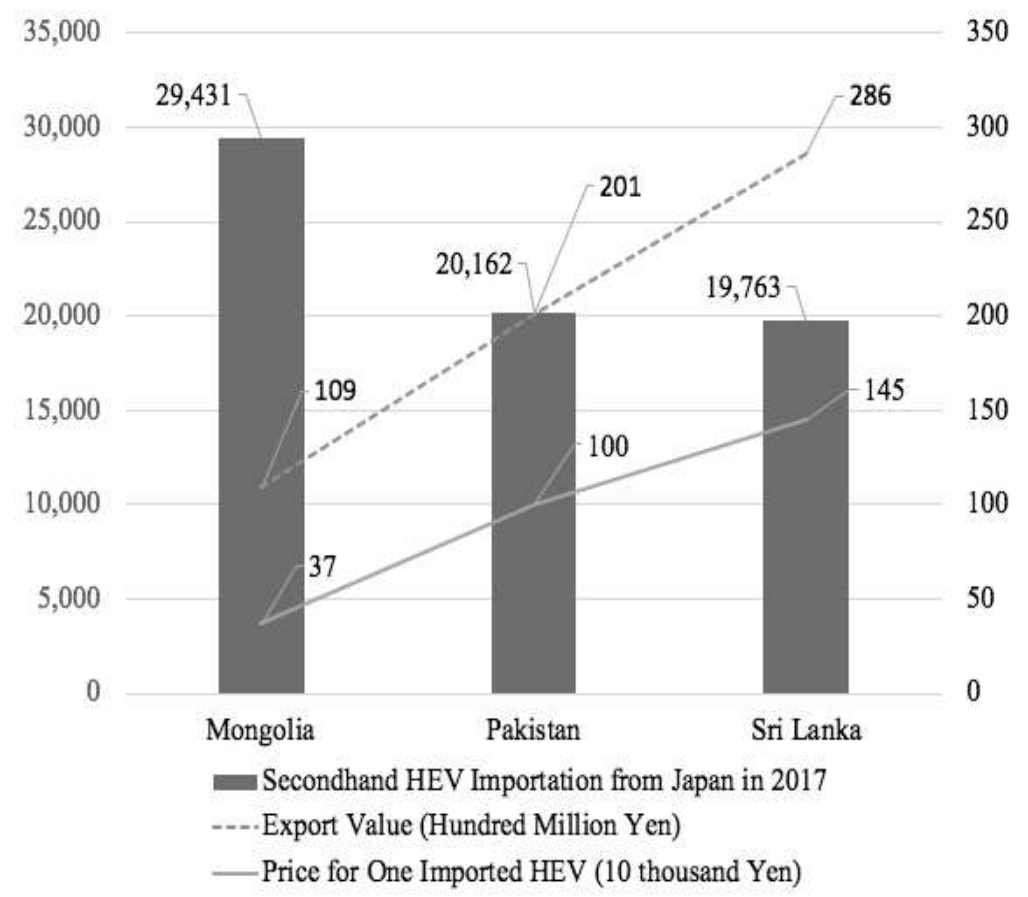

Figure 8: Price for Japanese secondhand HV exported to each country Source: Hamagin Research Institute 2018

\section{Recommendations and challenges for the future}

ELV recycling has been treated seriously in EU member nations. However, with the increasing secondhand vehicle exportation and the shortage of waste recycling facility, it is difficult to achieve the expected recycling target. Furthermore, as long as the vehicles' value is larger than ELV recycling cost, EPR is rarely useful. Although ELV recycling system has been installed in Germany, Italy, the Netherlands and secondhand vehicle importation countries in eastern Europe, ELV recycling rate is quite different in each country.

On the other hand, the Japanese government is monitoring the recycling rate for ELVs' airbag, CFC and ASR, and the recycling rate is close to $100 \%$. Moreover, discussions on the utility of Specified Recycling Deposit has started as well. However, since the standard for evaluating ELV recycling rate in Japan (three mentioned items only) is different from EU (recycling weight compared to the total weight of the ELV), the achievement cannot be judged on the same basis. The principal and cost allocation of EPR can be clarified only after these two patterns' suitability are verified strictly.

As secondhand vehicle exportation increases, advanced countries in EU, as well as Japan should discuss environmental effects as well. International assistance on ELV recycling technology/policy is important 
to prevent cross-border environmental issues ( $\mathrm{Yu}$ et al. 2017). Moreover, as NGV develops, secondhand NGV exportation, especially secondhand $\mathrm{HV}$ exportation is increasing at a fast pace. However, the international resource circulation system is not established yet, and should be discussed from this point.

In this research, vehicle makers' basic attitude on ELV recycling, as well as their plan for NGV recycling has been introduced. Normally, vehicle makers are all making and selling automobiles based on global sales strategy. However, the opinion towards ELV recycling and EPR is different and there is not enough preparation either. It is necessary that vehicle manufacturers make global vehicle recycling strategy based on EPR policy with common standard. In addition, international resource circulation system should also be considered.

To conclude, to build a new and sustainable vehicle industry, a network which can guarantee a stable supply of vehicle parts (secondhand parts included), assistance for pollution abatement facility, international cooperation in ELV recycling, and a smooth circulation for recycled resources is vital. 
Jeongsoo Yu, Shuoyao Wang, Kevin Roy B. Serrona: Comparative

Analysis of ELV Recycling Policies in the European Union, Japan and China

Bibliography

Automotive Industry Portal. 2017. Report of vehicle sales in Japan 2016. Accessed March $\quad 15, \quad 2018$. https://www.marklines.com/ja/statistics/flash_sales/salesfig_japan_2016.

Eurostat. "End-of-Life vehicles- reuse, recycling and recovery, totals." Accessed May 20, 2018. http://ec.europa.eu/eurostat/web/products-datasets//env_waselvt.

Fuji Keizai Marketing Research \& Consulting Group. 2016. "Research on global sale for $H V, P H V$ and EV." Accessed July 9, 2018. https://www.fujikeizai.co.jp/market/17059.html.

Hamagin Research Institute. 2018. "Static data for secondhand importation." Accessed March 3, 2018. https://www.yokohamari.co.jp/html/report/pdf/chuko1712.pdf, p.5.

Japan Automobile Recycling Promotion Center. 2016. JARC data book. Accessed March 3, 2018. https://www.jarc.or.jp/data/databook/.

Japan Automobile Manufacturers Association. 2018. Transition for the domestic sale for Next-Generation Vehicle. Accessed June 7, 2019. http://www.jama.or.jp/eco/earth/earth_o3_g01.html.

Japan Metal Bulletin. 2016. Domestic Iron scrap price. Accessed August 2, 2016. https://www.japanmetal.com/memberwel/marketprice.

MIZUNO. 2018. "Review on illegal dumping issue in Teshima." Accessed June 10, 2018. https://www.e-mizuno.co.jp/press57/.

Ministry of Economy, Trade and Industry. 2016 a. Suggestion for using Specified Recycling Deposit, document 22. Accessed December 12, 2017. https://www.meti.go.jp/shingikai/sankoshin/sangyo_gijutsu/haikibutsu_rec ycle/jidosha_wg/pdf/o44_s22_oo.pdf, pp.6-7.

Ministry of Economy, Trade and Industry. 2016 b. Situation for Next-Generation Vehicle. Accessed December 2016. https://www.meti.go.jp/shingikai/sankoshin/sangyo_gijutsu/haikibutsu_rec ycle/jidosha_wg/pdf/o38_so6_oo.pdf

Ministry of the Environment. 2013. Situation of final disposal site for industrial waste. Accessed March 2017. http://www.env.go.jp/council/former2013/o4recycle/yo4o-42/mato1.pdf.

Ministry of the Environment, Japan. 2002. Improvement for ELV reduction and recycling, Progress report of Central Environment Council. Accessed on March 19 , 2017. http://www.env.go.jp/press/file_view.php?serial=2578\&hou_id=2803.

MITSUBISHI. 2017. Environment report 2017. Accessed March 19, 2018. http://www.mitsubishielectric.co.jp/corporate/csr/download/csr/pdf/csr_r2 017.pdf.

Nippon Steel \& Sumikin Research Institute Corporation. 2016. Project to improve the spread of infrastructure and system with low requirements for energy in 2015 (Research on installing End-of-Life Next-Generation Vehicle in Mongolia)). Accessed August 2017. https://www.meti.go.jp/meti_lib/report/2016fy/o00332.pdf, p.41.

OICA, "Sales Statistics". Accessed December 18, 2017. http://www.oica.net/category/sales-statistics/.

OICA, "Vehicles in use". Accessed December 18, 2017. http://www.oica.net/category/vehicles-in-use/ .

Oliver-foundation, "Background of Teshima issue". Accessed December 11, 2017. http://www.teshima-school.jp/struggle/history/. 
SUBARU. 2017. CSR report 2017. Accessed March 20, 2018. https://www.subaru.co.jp/csr/report/pdf/2017/csr_report_2017_all.pdf.

Terazono A. 2002. ELV recycling status in Germany, Japan Society of Material Cycles and Waste Management, Vol.13, No.4, pp.210-220. Accessed November 11, 2017. https://doi.org/10.3985/wmr.13.210

The Japan Society of Industrial Machinery Manufacturers. 2014. "Vehicle recycling status in Europe (Part 1)." Accessed May 6, 2017. http://www.jsim.or.jp/kaigai/1406/o01.pdf.

TOYOTA. 2017. Environment report 2017. Accessed March 19, 2018. https://global.toyota/jp/sustainability/report/archives/.

Yano J, Xu G, Watanabe N, Sakai S. 2016. Resource potential of ELV and system evaluation on environmental burden. Accessed November 15, 2017. https://www.env.go.jp/policy/kenkyu/suishin/kadai/syuryo_report/h26/pdf /3K123001.pdf.

Yu J, Wang S, Toshiki K, Serrona KRB, Fan G, and Erdenedalai B. 2017. Latest Trends and New Challenges in End-of-Life Vehicle Recycling. Harrison RM, Hester RE (Ed.) Environmental Impacts of Road Vehicles: Past, Present and Future. London: The Royal Society of Chemistry Press, pp. 174-213.

Yano Research Institute. 2016. Research on basic technology for manufacturing in 2015, p.29. Accessed October $11 \quad 2017$. https://www.meti.go.jp/meti_lib/report/2016fy/ooo333.pdf. 